\title{
Re-examining the "Base": The Political and Security Dimensions of Turkey's Military Presence in Somalia
}

\author{
ASH ROSSITER ${ }^{*}$ and BRENDON J. CANNON ${ }^{*}$
}

ABSTRACT In late 2017, Turkey opened a facility to train the Somali National Army. Routinely described as a military base since, the move has caused consternation within and beyond the region and is held up as proof that a new scramble for Africa is underway. By contextualizing this new military mission within Turkey's wider role in Somalia, this article demonstrates why the term "base" is misleading and how training the SNA is consistent with Turkey's foreign policy aims in the country. As the SNA becomes a more powerful security actor, the article also shows how it may be (mis) used, by whom, and for what purposes, and identifies the risks this might pose for Turkey, Somalia and the wider region.

\section{Introduction}

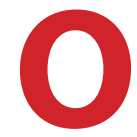

n September 30, 2017, Turkey officially opened a major military training installation in Somalia's capital Mogadishu. Omitting mention of Turkey's military presence in Northern Cyprus, Turkish and international media described the facility as Turkey's largest foreign military "base." For some observers, the opening of the facility, following the establishment of a base in Qatar and military intervention in Syria, was further evidence of a more muscular turn in Turkish foreign policy under President Recep Tayyip Erdoğan. ${ }^{1}$ Taking this further, some pundits extrapolated from these moves a desire by Ankara -or, more specifically, Turkish policymaking elites- to resurrect some vestiges of the former Ottoman Empire. For Decottignies and Cagaptay, the establishing of the Qatari base, which predated the inauguration of the Turkish facility in Mogadishu, signaled, using a rather implausible historical analogy, Turkey's return to the Indian Ocean after more than four hundred years, whence the Ottomans battled (unsuccessfully) with the Portuguese for supremacy. ${ }^{2}$ Explaining Turkey's current foreign policy in Somalia as somehow driven by its Ottoman past provides meagre explanatory power

* Khalifa University, United Arab Emirates

Insight Turkey Vol. 21 / No. 1 / 2019, pp. 167-188 
The TAF's involvement in the external security of the facility is probably less an indication of Turkey's sovereign use rights over this plot of Somali territory and more a reflection of the security situation in Somalia and the Somali security apparatus' inability to provide adequate protection at best and ignores the political and security goals of both Turkey and Somalia. It also ignores Turkey's increasing presence and significant investments in the rest of sub-Saharan Africa. ${ }^{3}$

There are, of course, some plausible reasons for linking Turkey's Somalia decision to a more assertive military posture. Firstly, foreign military "bases" are most commonly thought of as part of a state's infrastructure for war-making; that is, a critical means through which states

project military power abroad. When looking back over the latter half of the $20^{\text {th }}$ century, it is easy to see why this rigid interpretation of an overseas base's raison dêtre is prevalent. For, during the Cold War both rival blocs built up global networks of bases as part of a strategy that sought to "confront, encircle or intimidate the other side."4 The military rationale behind positioning forces abroad has, however, changed markedly since 1991, owing to the collapse of the Soviet Union, the emergence of non-traditional security threats and the widening of tasks that militaries across many parts of the world are asked to perform by their governments. ${ }^{5}$ In global basing trends, Cold War legacy bases have largely made way for smaller locations -often designated as 'installations,' 'facilities', or, in the particular lexicon of the U.S. defense establishment, as 'forward operating sites' or 'cooperative security locations' (rather than bases) ${ }^{6}$ - from which, and in which, various security-related tasks are performed, ranging from kinetic counter-terrorism operations to the delivery of training assistance to partner governments' security forces. ${ }^{7}$ This is increasingly true on the African continent where a host of states and international actors have established a military presence, either in the name of security assistance ${ }^{8}$ or to partner with local allies to counter-terrorism in the region. ${ }^{9}$

With a broadening of the functions overseas military deployments perform, understanding what is behind a foreign troop presence requires closer inspection than perhaps before. Nonetheless, because any presence of foreign military forces -in cases where they are not imposed on the host- is a conscious surrender by the host state of its military exclusivity within its territory, it is ineluctably a highly political decision. For this reason, new deployments offer great potential for analyzing relationships between the sending state and the host, as well those of both states with other state actors. Turkey's new military presence in Mogadishu is thus an opportunity to explore wider questions 
about Ankara's evolving and deepening involvement in Somalia and the region. Equally, analyzing Mogadishu's decision -and, as will be shown below, it was a decision; Turkey has not imposed a military presence on Somalia- to agree to this Turkish mission can shed new light on successive Somali Federal Governments' (SFG) national security priorities and how they manage their external relationships.

In order to delve into these issues, the remainder of the article proceeds as follows. The first section describes the operational purpose of the new Turkish military presence in Somalia. In particular, it explicates why the term "base" is misleading and shows how the stated function of the Turkish troops in Somalia -to train the Somali National Army (SNA) - is consistent with the contemporary activities of the Turkish Armed Forces (TAF). The next section places the deployment decision within the wider context of an intensification of Turkey's role in Somalia, especially since 2011, explaining how the training mission complements Turkey's foreign policy aims. The article then turns to explore Somalia's interests in hosting the Turkish facility and the benefits it may see from training the SNA. In the fourth section, we consider the security and political implications of the new Turkish military presence in Somalia for both sender and host, as well as the Horn of Africa and wider region, paying particular attention to how misuse of the term "base" has led both politicians and pundits mischaracterize Turkey's military training role in Somalia as a projection of hard power. The fifth section forms the conclusion.

\section{The "Base" that Is Not a Base}

Though neither the cost of the so-called Turkish "base" (a reported \$50 million in capital expenditure) nor the size of the military commitment it houses (around 200-300 Turkish soldiers and officers) is especially large, its opening received extensive international media coverage and triggered much discussion about Turkey's military posture in the Horn of Africa. ${ }^{10}$

Turkish officials were quick to correct media reports claiming that Turkey was constructing a military base in Mogadishu. Indeed, they had tried before the inauguration of the facility to rid it of the "base" label. In an interview with Turkish media six months before the facility was complete, Turkey's ambassador to Somalia, Olgan Bekar, clarified that it was "not a military base like the one Turkey has in Qatar," but "a military training camp."11 The ambassador's choice of Qatar to contrast the Somalia deployment was apposite: the Qatari base entails an operational contingent of the TAF that includes ground forces and artillery units; the facility in Mogadishu houses a Turkish military training team. ${ }^{12}$ The difference in the purpose of the two bases became even starker after the Turkish parliament's ratification on June 7, 2017 of a bilateral defense 
bill with Doha and the deployment of additional Turkish forces to Qatar. ${ }^{13}$ Reports in the Turkish press, however, have done little to dispel the commonly held view that the training facility is a base. Indeed, they have reinforced it. This is not a case of concepts or terms being confused with one another in Turkish: askeri eğitim tesisi means military training facility; $\ddot{u} s$ or askeri üssü or askeri eğitim üssü mean "base/military base/military training base." Rather it seems, based on the tone and content of the articles, more a result of interest and pride in Turkey's military role outside its borders. $^{14}$

As discussed above, military basing is often viewed along a spectrum. A site where forces are permanently deployed to deter foes, provide the initial reaction to military threats and to reassure allies is usually considered a base. ${ }^{15}$ In contrast, Turkey has deployed its military personnel for a training mission rather than to project hard power. A cadre of over 100 Turkish military instructors ${ }^{16}$ has already begun delivering a standardized military curriculum to batches of 1,500 Somali soldiers, non-commissioned officers and officers. The remaining Turkish troops -another 200 or so- protect the site from attack. In functional terms, the Turkish military presence is not an overseas base.

Definitions of what constitutes an overseas "base," rather than a "facility," also typically require a cession of territorial sovereignty by the host, providing the user nation with high levels of discretion over the use of the site. ${ }^{17}$ While it remains unclear what precise use rights Turkey has over its Mogadishu facility -it is plausible Turkey does have some form of lease for the land housing the facility for an unknown number of years ${ }^{18}$ - foreign military advisory missions and their training establishments do not usually entail such a cession. ${ }^{19}$ Moreover, the TAF's involvement in the external security of the facility is probably less an indication of Turkey's sovereign use rights over this plot of Somali territory and more a reflection of the security situation in Somalia and the Somali security apparatus' inability to provide adequate protection. Indeed, the training facility has reportedly already been the target of al-Shabaab attacks. ${ }^{20}$ 


\section{What differentiates the Somali case from others is the sheer depth of Turkey's multifaceted involvement in the country since 2011. The new Turkish military presence cannot be understood outside of this context}

That Turkish military personnel have been deployed to conduct an overseas training mission is not unusual. To be sure, during the Cold War the TAF, equipped, organized and positioned for defensive operations within the collective security context of NATO, was poorly suited for tasks other than major conflict. ${ }^{21}$ Since 1991, however, the Turkish military has participated in a range of multilateral peace support operations ${ }^{22}$ and training missions, including NATO's Partnership for Peace (PfP) programs. ${ }^{23}$ Concomitantly, the TAF reorganized in the early 1990s so it could perform non-traditional tasks increasingly emphasized in Turkey's emerging defense posture. ${ }^{24}$ Turkey's aspiration to be viewed as a key player in peacebuilding on the global stage resulted in Ankara utilizing its security forces more and more as a soft power tool ${ }^{25}$ (The 1991-2005 Turkish gendarmerie training mission in the Republic of Gambia is an illustrative case of this wider trend). ${ }^{26}$ The Turkish military deployment to Somalia dovetails with Ankara's broader efforts to bring "softer" forms of power to bear upon security challenges. Although the training mission in Somalia fits in with an overall pattern of how Ankara uses its military for foreign policy aims, the case of Somalia is arguably sui generis. What differentiates the Somali case from others is the sheer depth of Turkey's multifaceted involvement in the country since 2011 . The new Turkish military presence cannot be understood outside of this context.

\section{Turkey's Holistic Role in Somalia}

Since 2011, Turkey has made Somalia a major focus of its foreign policy. Arguably, Turkish involvement in Somalia represents the first time Ankara has attempted to bring a vision of durable peace to another country. Turkey's presence in Somalia certainly embodies one of the most interesting, but widely misunderstood regional geopolitical developments in the past decade. Genuine humanitarian concerns, at least initially, drove Turkey's engagement in efforts to alleviate a widespread and devastating famine in 2011-2012. ${ }^{27}$ The prospect of economic gain has played an equally important role in Turkey's developing relationship with Somalia. In the six years spanning 2011-2017, Turkey moved from being an economic footnote in Somalia to its fifth-biggest source of imports. ${ }^{28}$ Turkey's engagement has been unique in that it 
What is different today is that Turkey's security-related efforts are intertwined with a much wider agenda to rebuild the country's infrastructure and, in so doing, assist in trying to rebuild Somali public institutions ruined by civil war tangible and lasting, as manifest in hospitals, schools and roads. ${ }^{29}$ Less tactile forms of aid such as scholarships, training and diplomatic efforts aimed at fostering political dialogue are targeted, coordinated from Ankara, and largely unilateral in nature. ${ }^{30}$ Turkey's approach to Somalia has been characterized by Donelli and Levaggi as hybrid and non-traditional because "it combines the traditional political-sta-

bility perspective of western powers with the economic-trade perspective of emerging ones." ${ }^{31}$ This separates Turkish aid and support from the disjointed overlap and brevity that have characterized aid and capacity-building efforts by other states in Somalia for the past two decades. ${ }^{32}$

As Turkey's initial investments and efforts for influence in Somalia paid off in the form of infrastructure contracts, Turkey found itself refurbishing, expanding and managing both Mogadishu's international airport and its seaport, between them reportedly the source of approximately 80 percent of the SFG's revenue. ${ }^{33}$ Though Turkey may not be making as much money from its investments as initially estimated, ${ }^{34}$ its control of Somalia's most critical and lucrative infrastructure along with its substantial humanitarian aid necessarily make Turkey an important political actor in Somalia because of the leverage over, and the relationship it has, with the SFG. ${ }^{35}$ This means that Turkey has become one of the most significant actors in the calculations of Somali politicians. ${ }^{36}$

Yet the larger rationale for Turkey's "choice" of Somalia lies in more intersubjective realms. In short, Turkey is also involved in Somalia to accrue political capital in the form of international prestige. ${ }^{37}$ This becomes apparent when looking at Turkey's initial decision to involve itself in the country. This was made at the highest level of government and forms part of a highly personal outreach by President Erdoğan to various states and leaders that has characterized the latter decade of Erdoğan's rule and which is firmly rooted in the "Ankara criteria." ${ }^{38}$ It is also part of a wider strategy aimed at enhancing Turkey's global image and soft power and Erdoğan's own attempts to leave a lasting, positive legacy. ${ }^{39}$ As importantly, Turkey's role in Somalia plays well with Erdoğan's voter base which believes he and his AK Party government are making Turkey a great power. ${ }^{40}$ Gullo noted at the beginning of Turkey's foray in Somalia: "As Turkey's latent power grows, it will seek out [...] opportunities to use its soft power via international activism to achieve its wide-ranging national interests of becoming a regional and global power." ${ }^{31}$ 
In terms of security, what is often forgotten by academics, policymakers and pundits is that Turkey was involved in Somalia prior to 2011, most notably through its participation in the first UN Operation in Somalia (UNOSOM I), and subsequently by the appointment of a Turkish general, Çevik Bir, as the force commander of UNOSOM II in $1993 .{ }^{42}$ What is different today is that Turkey's security-related efforts are intertwined with a much wider agenda to rebuild the country's infrastructure and, in so doing, assist in trying to rebuild Somali public institutions ruined by civil war. In this context, it makes sense that Ankara would consider its role in building up the SNA as a generational commitment. Indicative of Turkey's long-term approach to its involvement with the army, Somali military students will be taught Turkish; mid-level and high-ranking SNA officers will receive training in Turkey in order to be socialized in the Turkish version of NATO practices; ${ }^{43}$ and the SNA will be equipped with arms produced in Turkish factories. ${ }^{44}$ In sum, the scale of Turkey's training mission is commensurate with its ambitions for the country.

Turkey's investments in Somalia have been significant and, if the words of its leaders are taken at face value, are meant to lead or contribute to a stable and prosperous Somalia. In this, Turkey supports the overarching agenda of other major international actors such as the U.S., UK and the UN that Somalia should revert to its pre-civil war status as a unified, stable and sovereign state. ${ }^{45}$ To this end, Turkey's focus on building the SNA into a truly national force is logical. The SNA has the potential to be the most powerful security actor in Somalia but is currently in a deplorable state.

The output of Turkey's overseas military training mission is, of course, to remedy this situation and render the SNA and thereby the SFG more effective in broadcasting power throughout the country and eventually establishing a monopoly over the means of legitimate coercive force in Somalia. Ankara's direct goal in training the SNA is to create a cohesive force strong enough to handle security duties in the country within and beyond the capital Mogadishu. Yet, regardless of the detractions or praiseworthy nature of Ankara's changing and growing role in the country, greater stability in Somalia has implications for wider Turkish security aims. As General Hulusi Akar, then the TAF's highest ranking officer, told an audience of Somali and Turkish officers during the facility's opening ceremony, Somalia has strategic importance in terms of the fight against terrorism and the security of East African sea lanes. ${ }^{46}$

\section{What Mogadishu Wants}

Whilst Turkey and Somalia are in a hierarchical relationship, the deployment of Turkish military personnel cannot be fully understood without considering what Somalia hopes to gain from their presence. ${ }^{47} \mathrm{~A}$ fundamental prob- 


\section{By training the SNA almost in toto and over a generation, Turkey has arguably made a longer-term commitment to Somalia's security and stability than any of the country's other foreign backers}

lem facing state-builders in Somalia -and in much of the rest of sub-Saharan Africa, for that matter- has always been their inability to effectively project authority over large, often inhospitable and under-populated territories. ${ }^{48}$ Somalia's population is centered overwhelmingly in the capital, Mogadishu, but alternative population centers stretch across its vast geography from, south to north, Kismayo to Garowe to Hargeisa, for example. Additionally, the federal government's reach is also curtailed over much of the country by Puntland's political autonomy and because Somaliland is de facto independent (albeit internationally unrecognized as such). ${ }^{49}$ Thus, problems of broadcasting power effectively in Somalia are complicated by both geography and politics.

The SFG, sometimes referred to as the "Mayors of Mogadishu" because their writ of the government is said to be limited to areas surrounding presidential palace and residence, has expressed its ambition to broadcast power across the entire state -something that has not been achieved since the outbreak of the Somali Civil War in $1991 .^{50}$ The SFG cannot achieve this while reliant on foreign troops pursuing their own agendas. It can only do so with an army of sufficient heft. As such, Turkey's offer to undertake the training of a nascent SNA - reported on social media, perhaps too optimistically, to be composed of Somalis from north to south including members of state militias- is fully congruent with and supports the SFG's ultimate goal of a unitary, fully sovereign state ruled from Mogadishu. ${ }^{51}$

There seems nothing to suggest that the current SFG of President Mohamed Abdullahi Mohamed aka Farmajo or that of his predecessor, Hassan Sheikh Mohamud, at least on the surface, does not share the same goal as Turkey: to build up the SNA into a coherent and more capable force. Additionally, all appearances seem to point to the fact that Ankara did not impose this military mission on Somalia and that the SFG understands the urgency of building up an army as much, if not more, than Turkey does. This is because the African Union Mission in Somalia (AMISOM), the regional peacekeeping mission operated by the African Union (AU) with the approval of the United Nations, has said that it will start a phased withdrawal by October 2018, though reports indicate that some troops have already departed. ${ }^{52}$ In September 2017, Somalia's ambassador to the United Nations, Abukar Osman, warned the UN Security Council that "the Somali National Army is not ready to take over the security 


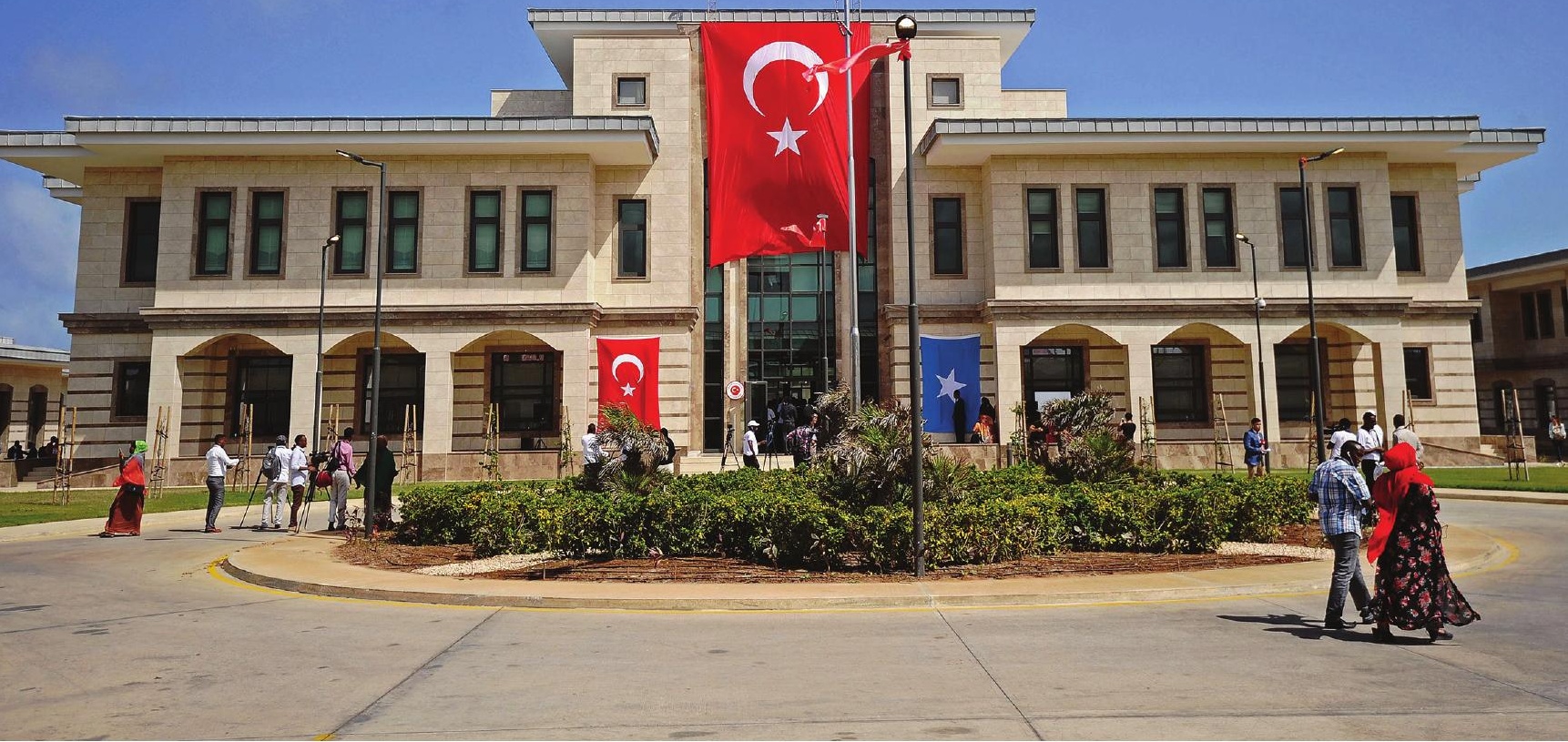

The newly opened Turkish embassy of the country." Premature withdrawal of AMISOM, he said, might be a "recipe for disaster." ${ }^{33}$ Ahmed Moallim Fiqi, the former director of Somalia's National Intelligence and Security Agency (NISA), recently remarked that the current Farmajo government is feeling the pressure to get the SNA in order. "The Somali government is under a constant reminder that time is running out for AU [AMISOM] troops, and the only troops who can replace them are Somali soldiers," he told reporters. ${ }^{54}$ In response to AMISOM's declaration that it was planning a troop withdrawal, Somalia published a plan in 2017 to establish a 22,000-strong army (at least 18,000 regular troops and 4,000 Special Forces). In this regard, Turkey's training mission could not be timelier for the SFG. Additionally, it supports a key pillar -the training of an SNA- of the 2017 Security Pact, signed in London and supported by 42 foreign governments and international bodies. ${ }^{55}$

While Somalia's security remains fragile, particularly to the south and west of Mogadishu, the security that does exist rests to a large degree on the presence of AMISOM forces. Yet AMISOM was always meant to be a temporary mission, and a number of external parties have been attempting to reform and improve Somalia's institutions for some years. AMISOM and Western governments have pinned their aspirations for a stable and unified Somalia, rather forlornly, on the idea that a professionally trained and equipped Somali army, along with a reformed Somali Police Force (SPF) and NISA, would eventually bring this to pass. ${ }^{56}$ To date, piecemeal attempts to rebuild and improve these organizations have failed to yield significant results in large part because of the inability or refusal of the primarily Western donor governments promoting the largest Turkish embassy in the world. Turkey has sponsored aid and health facilities amongst other projects in Somalia.

MOHAMED ABDIWAHAB / AFP / Getty Images 
Security Sector Reform (SSR) to grasp the nature of the security environment in Somalia, which is characterized by "personalized or neopatrimonial relationships and inter-agency rivalries conducted amongst and between political elites and security actors such as police, militaries, intelligence agencies, special units, warlords, militia and commercial security companies." 57 Additionally, when such training missions interact with sub-state security groups, the intentions of the trainees are rarely congruent with those of the trainers. Given that many security organizations operating in Somalia are little more than business projects designed to empower and enrich "diverse actors competing for influence and resources," they often view capacity-building efforts by international actors as entrepreneurial opportunities. ${ }^{58}$

The SNA came into existence in 2004, upon the creation of the first Transitional Federal Government (TFG) following the cessation of the Somali Civil War. The outgrowth of an agreement to integrate the militias of different warring factions, the SNA remains a highly fractionized force. Poor training, lack of funding, and endemic corruption have all sapped the SNA of effectiveness. ${ }^{59}$ Complicating matters further, over the past decade Somali troops have been trained in different countries, including Kenya, ${ }^{60}$ Uganda, Ethiopia, Djibouti, the United Arab Emirates (UAE), and by different countries and international organizations, including the U.S. and the European Union. ${ }^{61}$ This piecemeal approach to training has arguably served to further fractionize the SNA as well as other Somali security agencies. There is some evidence that certain units within the Somali security sector operate outside the authority of elected officials in Mogadishu and more under the direction of their foreign trainers. ${ }^{62}$ Problems associated with lack of federal government control over the country's various security forces were underscored at the end of 2017 when an unidentified military unit raided the house of a senior politician. ${ }^{63}$ This situation is potentially highly dangerous. The presence of armed groups organized along clan lines and manipulated by external parties and Somali political elites led to massive violence in Mogadishu in 2007-2008. ${ }^{64}$

Given the above-described situation -particularly the disjointed way various parties have provided security assistance in Somalia and AMISOM's looming departure- Turkey's offer to train the SNA under a consistent curriculum and supply the force with similar (Turkish) equipment was warmly welcomed by the Somali government. Furthermore, by training the SNA almost in toto and over a generation, Turkey has arguably made a longer-term commitment to Somalia's security and stability than any of the country's other foreign backers. Unlike previous training efforts that were limited in duration and relegated to the training of small military units, Turkey has voiced its understanding of the necessity of a truly national army and, concurrently, signaled its willingness to provide such training. ${ }^{65}$ At least some leaders in Mogadishu recognize the importance of what Turkey is attempting, and media coverage surrounding the 
opening of the military training facility has been largely positive. For example, the Somali Information Minister at the time of the facility's opening remarked: "This is something that Somalia has never seen even though countries like the U.S. and UK are giving us millions. The difference is the camp Turkey built is an institution that will remain for the next 50 or 100 years." ${ }^{66}$ Somali officials do not seem perturbed by the prospect of becoming dependent on Turkish support for the functioning of the SNA. Instead,

Somali government officials have very publicly demonstrated how much they welcome Turkey's deepening security role in Somalia.

\section{Possible Implications}

There has been speculation by some that the opening of the training facility in Somalia is but the first stage in a much larger and enduring Turkish security role in the Horn of Africa. According to one analyst, "Ankara wants to strengthen its geostrategic position in the world by politically, financially and militarily engaging with the Horn of Africa. Indeed, Turkey's military base in Somalia is very close to the entry point of the Gulf of Aden." ${ }^{67}$ The idea that Turkey is using its new military presence in Somalia as a beachhead for a much larger strategic gambit in the region, however, does not stand up to scrutiny. Turkey's "largest overseas military base" cannot in definitional terms (certainly militarily and perhaps legally) be considered a base, as highlighted previously. While Turkey's training facility may be large in terms of area, it certainly pales in comparison to other Turkish troop deployments as of mid-2018. ${ }^{68}$ At the time of writing, Turkey maintains over 40,000 troops in Cyprus, reportedly has deployed over 5,000 to Syria, and has 2,500 and 2,000 troops stationed in Iraq and Afghanistan, respectively. Even tiny Kosovo is home to 400 Turkish soldiers who serve as part of the Kosovo Force (KFOR), a NATO-led international peacekeeping force. Unless Turkey's contingent of soldiers in Somalia rises significantly, it is insufficient to project power in any meaningful way beyond that of a training facility protection force, as intended. On the face of it, Ankara's motives behind its military presence are ostensibly more similar to those of the European Union's training mission in Somalia ${ }^{69}$ than the United States' expanded footprint in the country, with the latter's greater emphasis on counter-terrorism in the wider Horn of Africa/Red Sea area. ${ }^{70}$ 
Moreover, given that Turkey's current national security priorities lie so overwhelmingly in its immediate neighborhood, it is highly unlikely that Ankara is about to carry out a major repositioning of military resources to the Horn of Africa/East Africa area. It is also difficult to draw a strong line between establishing a training mission in Somalia and increasing Turkey's political clout in the wider region. As our analysis attempts to show, the new military presence is a natural extension of Turkey's deepening involvement in Somalia's development and should be understood primarily in this way.

It remains to be seen how much influence over Somali politics Turkey will derive from its enhanced security role, particularly through its tutelage of the SNA. Unequal security relationships involving a military presence can often lead to the host state's domestic authority structures being compromised by the sending state. Leaders agreeing to enter into bargains with security patrons harbor the same fears as the King of Siam from the Rogers and Hammerstein musical The King and I, who asseverated in song: "If allies are strong with power to protect me, might they not protect me out of all I own?" ${ }^{\text {11 }} \mathrm{Re}$ ferring to his country's impending military deployment, Turkey's ambassador to Somalia, Olgan Bekar, stressed that Turkey had "no colonialist policy in Somalia." 72 Yet, Turkey is far from a disinterested party; it is deeply invested in the Somali political scene. There are many past examples of how military support is used to achieve what Scott has referred to as "techniques of informal penetration." ${ }^{33}$ Additionally, though the Turkish military presence is not tied directly to Turkey's expansive aid program and economic assistance, it may still buy Turkey a high degree of tolerance for its activities in the country. ${ }^{74}$ This is not currently a problem for, at present, there appears to be a high level of goal congruence between Mogadishu and Ankara, but this can always change, as alluded to below. And if it does, the fact that Turkish-Somali relations are hierarchical may become more apparent.

To date, there are few indications that Turkey is seeking direct involvement in Somalia's security. The training mission is in place for clearly stated ends using specific means. There is a danger, however, that Somali leaders may misread the level of Turkey's commitment. Officials may come to believe that by having troops in the country, Turkey is playing a protective role. Although the Turkish-Somali agreement governing the military presence almost certainly does not include a casus foederis clause (stipulating that if Somalia is attacked, Turkey is obligated to come to its assistance), the Somali government has presented the Turkish deployment as a visible and real political commitment to the country by an ally. In patron-client arrangements, clients can often overestimate the willingness of the patron to take on risks on their behalf. ${ }^{75}$

As Turkey's goals will not always share a high degree of congruence with those of Somalia's leaders it may be worth remembering the words of a 2012 pol- 
icy briefing by the International Crisis Group: Turkey must "remain impartial in internal politics and avoid being manipulated by Somali politicians long experienced in outwitting foreign newcomers."76 While Turkey is certainly no longer a newcomer to Somalia and the choice of words regarding Somali politicians may be ill-advised, there is little doubt that one of the pitfalls of training the SNA means that Turkey may get pulled by Somali politicians in directions it wishes to avoid. These include clan favoritism, regionalism, factionalism and, above all issues involving territorial integrity. ${ }^{77}$ Turkey may find this increasingly hard to avoid as the SNA, and therefore Somalia, become increasingly reliant on Turkey for the expertise, skillsets and matériel required to maintain the SNA.

It is difficult to estimate the level of informal over-

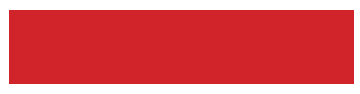

Unless Turkey's contingent of soldiers in Somalia rises significantly, it is insufficient to project power in any meaningful way beyond that of a training facility protection force, as intended sight Turkey will establish over the SNA. Nonetheless, Turkey will surely find its advisory role a challenging one. The goal is clearly to build the SNA into a competent and crucially, apolitical security institution. But it is highly unlikely that Turkish efforts will successfully transcend the personalized or neo-patrimonial relationships between political elites and unit commanders that characterize how state security organizations are run and used in Somalia. ${ }^{78}$ Turkey would not be the first country to struggle with this problem. Since 2003, U.S.-trained forces in Iraq and Afghanistan, for example, have often been used for criminal purposes or political schemes by their local commanders. ${ }^{79}$ Additionally, the proliferation of militias that range from the army fielded by the break away and de facto independent Republic of Somaliland, ${ }^{80}$ to clan-based and/or regional militias such as those operating in the semi-autonomous regions of Puntland and Galmudug, ${ }^{81}$ means the Turkish-trained SNA will almost certainly be viewed with suspicion by officials in Puntland and would-be secessionists in Somaliland. ${ }^{82}$

Pooling large amounts of coercive power in one place -i.e. the SNA- may be viewed as a challenge by other power brokers and sub-state actors operating inside and outside of Mogadishu. This will become particularly sticky should other security actors supported and trained by various international actors, such as the police or intelligence services, challenge or disagree with the Turkish-trained and -equipped SNA. This is, in part, because of the nature of previous SSR efforts in Somalia. It also stems from the fact that major international actors such as the U.S., the UK and the United Nations Development Program (UNDP) have voiced their support for -and made efforts to ensure- a unitary Somalia, but one that contains a multiplicity of security actors rather than a 


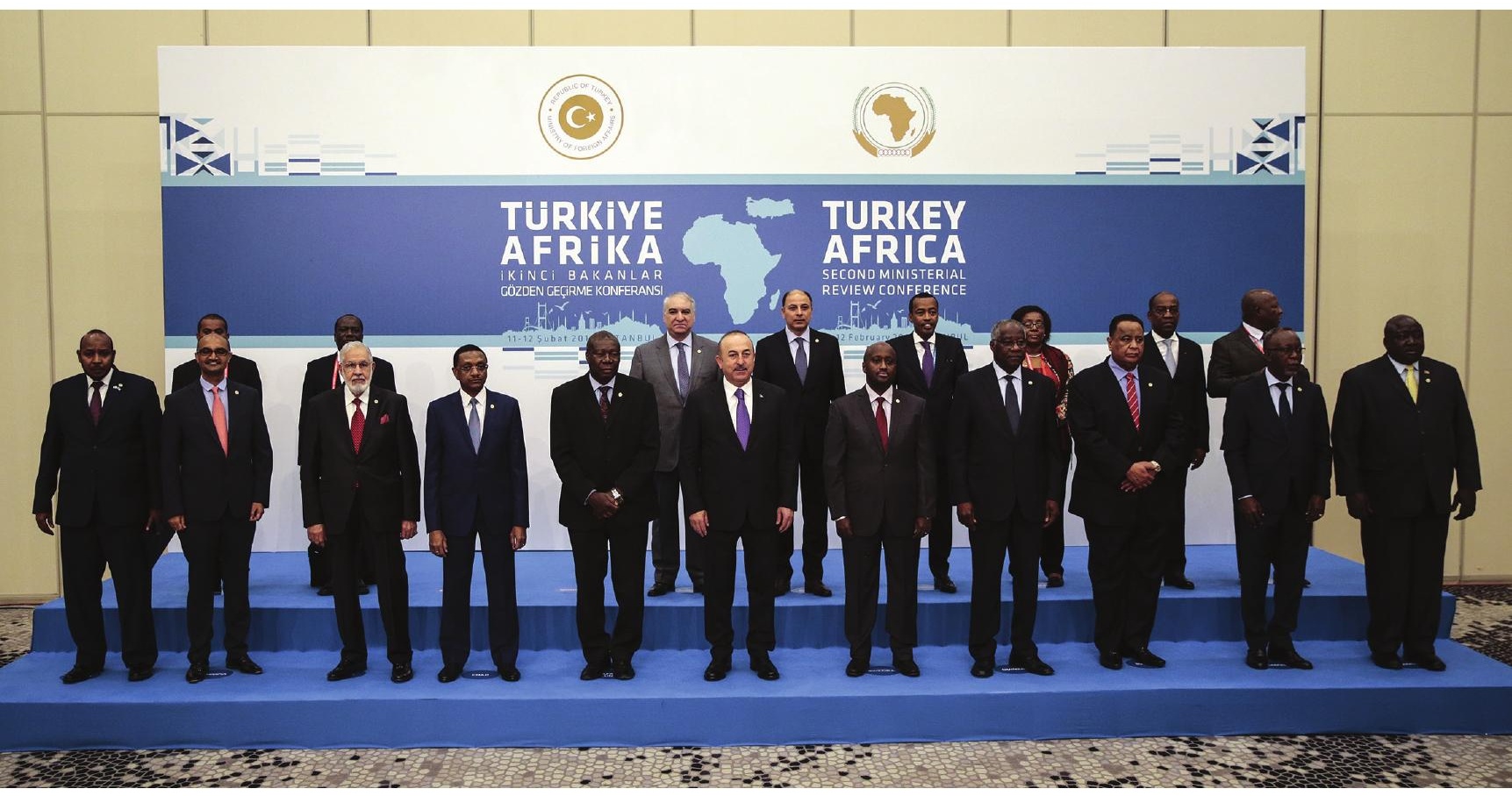

African FMs with the Turkish FM,

Mevlüt Çavuşoğlu, pose for a family photo during the Turkey-Africa $2^{\text {nd }}$ Ministerial Review

Conference in Istanbul on February 12 ,

2018.

SERHAT ÇAĞDAŞ / AA Photo

single security sector. As such, Turkey may be unwittingly adding fuel to the fire of armed conflict between various and extant security actors currently operating in Somalia. ${ }^{83}$ Should this be the case, the SNA may be viewed as Turkey's proxy force and thereby find itself in conflict with other proxy actors or, at the very least, those trained, funded and armed by other states.

Outside of Somalia, Turkey's SNA training mission has reignited certain fears in eastern Africa and been the cause of some alarm across the Gulf of Aden. A revitalized and well-equipped SNA necessarily means it might one day project force outside Somalia's territorial limits. The irredentism inherent in the dream of a Greater Somalia (Soomaaliweyn) may have been crippled after the Ogaden War (1978-1979) and largely buried for the 25 years since the outbreak of the Somali Civil War, but the resurgent and vocal nationalism voiced by Somalia's new president Farmajo during the 2017 presidential campaign means it still causes heartburn in Nairobi and Addis Ababa. ${ }^{84}$ Somali social media is demonstrative of a sentiment that Turkey's assistance to Somalia is the cause of deep concern to Kenya and Ethiopia and may herald a settling of regional scores. ${ }^{85}$

The concerns of the Gulf Arab States figure more prominently in international media where recent moves and agreements by states such as the UAE and Saudi Arabia have been construed by the media as a race or competition between Turkey and the aforementioned states. ${ }^{86}$ According to some, Ankara has begun to 
worry about its strategic interests in Somalia and the Horn of Africa and thus militarize its presence in order to stave off any threats to its influence and assets in Mogadishu. ${ }^{87}$ Even though most reports generally admit, for example, that the military facility in Mogadishu "will be focused more on assisting Somalia than demonstrating Turkish military capabilities," the headlines project a different tone entirely. ${ }^{88}$ Recent disagreements within the Gulf Cooperation Council (GCC) have also contributed to tensions, demands for choosing sides, ${ }^{89}$ and an increasing urgency to the sense of competition in Somalia. ${ }^{90}$ Saudi Arabia and the UAE see gains for Turkey in Somalia as working to the advantage of their bete noir, Qatar, with which Ankara is closely allied. In this zero-sum framework, and with a plethora of proxy-trained, equipped and salaried forces already operating in Mogadishu, Turkey's training of the SNA may be perceived by Riyadh and Abu Dhabi as just one more effort aimed at further entrenching the influence and power of a Turkish-Qatari axis in Somalia. Thus, while violence is by no means inevitable, it appears increasingly likely at either the local level, the regional level or as an arena for international proxy conflict.

\section{Conclusion}

Turkey's training mission is by far the most ambitious attempt at SSR by any external actor in Somalia in recent years. Perception-wise, the decision has not been framed by Somalis as a penetration of sovereignty by Turkey. Rather it appears to be a change that is cautiously welcomed, in that it may provide perhaps the best means yet to realize a stable, federal Somalia as ruled from Mogadishu. As noted, this type of large-scale planning and commitment of time and resources has been sorely lacking in previous efforts to train various security elements, which have been piecemeal, generally short-term and unfocused.

Turkey's current foreign policy cannot be explained away as being driven by some ill-defined neo-Ottoman agenda or as an overly simple effort to protect its assets in Somalia with hard power. Rather, we argue that Turkey's recent military presence in Somalia is a logical extension of its growing economic and political involvement, as well as Turkey's increased propensity for using the TAF for soft power aims. Turkey does not need a military base or troops in Mogadishu to project power. The reality of Turkish power in Mogadishu was present 
Turkey's recent military presence in Somalia is a logical extension of its growing economic and political involvement, as well as Turkey's increased propensity for using the TAF for soft power aims prior to the building of the military training facility and manifests itself in the management of strategic economic assets and critical infrastructure as well as the revenue they produce and upon which the SFG is reliant.

We add a cautionary and prescriptive note, however. Turkey must focus on the functional role of the army as much as its future institutional role. That is, the current idea in Ankara of what an SNA should look like is likely based on the Turkish military model, a NATO-stan-

dard model that sees SNA officers and enlisted men alike eventually operating within what Peter Manning has described as a "bureaucratic, rule-oriented, hierarchical structure of command and control on the one hand, and a loose confederation of colleagues on the other." ${ }^{\text {"1 }}$ While this type of Westphalian or Weberian ideal may not figure as prominently in the minds of Somalias current leaders, the ideal of the pre-civil war Somali state in which Mogadishu effectively broadcasts power throughout the state certainly does. Thus, the danger is not only that Turkey's ideal SNA may, in the end, be delusional, but that whatever form it does take -and Turkey will attempt to train an army- may be viewed and used by the SFG as the ultimate means to finally put Somalia back together again. In the process, Somalia's variously trained and equipped forces may see their ventures curtailed, thus leading to another round of violence this time backed by international actors interested in maintaining their influence and interests in Somalia.

\section{Endnotes}

1. "In the Race between the UAE and Turkey, Somalia Wins," Stratfor, (August 14, 2017), retrieved from https://worldview.stratfor.com/article/race-between-turkey-and-uae-somalia-wins.

2. Olivier Decottignies and Soner Cagaptay, "Turkey's New Base in Qatar," Washington Institute for Near East Policy, Policy Watch No. 2545, (January 11, 2016), retrieved from http://www.washingtoninstitute. org/policy-analysis/view/turkeys-new-base-in-qatar. For Turkish media stories with a similar tone and content, see, Uğur Ergan, "Somali'ye Türk Askeri Eğitim Üssü [Turkish Military Training Base in Somalia]," Hürriyet, (January 18, 2016), retrieved from http://www.hurriyet.com.tr/dunya/somaliye-turk-askeriegitim-ussu-40042244; İzzet Kaya and Emrah Yeşilduman, "Türkiye Osmanlı Topraklarına Geri Dönüyor [Turkey Returns to Ottoman Lands]," Yeni Şafak, (January 3, 2018), retrieved from https://www.yenisafak. com/gundem/turkiye-osmanli-topraklarina-geri-donuyor-2951575.

3. For example, next-door Ethiopia receives the largest percentage of Turkish direct investment in Africa, attracting over 40 percent of such investments. On this point refer to Brendon J. Cannon, "Turkey in Africa: Lessons in Political Economy," Florya Chronicles of Political Economy, Vol. 3, No. 1 (2017), pp. 93-110; Jacqulyn M. Kantack, "The Gulf Contest for the Horn of Africa," Critical Threats, (September 26, 2017), retrieved from https://www.criticalthreats.org/analysis/the-gulf-contest-for-the-horn-of-africa.

4. Zdzislaw Lachowski, "Foreign Military Bases in Eurasia," Stockholm International Peace Research Institute, Policy Paper No. 18, (June 2007); see also, Christopher Sanders, America's Overseas Garrisons: The Leasehold Empire, (Oxford: Oxford University Press, 2000). 
5. On this point refer to Dale W. Meyerrose, Overseas US Bases: Cold War Relics or Essential to US Strategy?, (Washington D.C.: National War College, 1992). For a more general discussion on the changing utility of bases to address contemporary security problems see, Simon Duke, "Under Paid, Under Sexed and on the Way Out? The Past, Present and Future of US basing in Europe," in Luis Rodrigues and Sergiy Glebov (eds.), Military Bases: Historical Perspectives, Contemporary Challenges, (Amsterdam: IOS Press, 2009), pp. 3-16.

6. U.S. Defense Department, Strengthening US Global Defense Posture and US Congress, Options for Changing the Army's Overseas Basing, (Washington D.C.: Congressional Budget Office, May 2004), p. 10.

7. The exemplar is the U.S., which, since the Second World War, has maintained by far the most extensive network of overseas military bases. It has shifted from large Cold War legacy bases to smaller locations largely on account of the Global War on Terror. See, for example, Robert D. Critchlow, US Military Overseas Basing: New Developments and Oversight Issues for Congress, (Washington, D.C.: Congressional Research Service, 2005); Kurt M. Campbell and Celeste Johnson Ward, "New Battle Stations?" Foreign Affairs, Vol. 82, No. 5 (2003), pp. 95-103.

8. Emma Skeppström, Cecilia Hull Wiklund and Michael Jonsson, "European Union Training Missions: Security Sector Reform or Counter-insurgency by Proxy?" European Security, Vol. 24, No. 2 (2015), pp. 353-367.

9. See, Jeremy Keenan, The Dark Sahara: America's War on Terror in Africa, (London: Pluto Press, 2009); Gorm Rye Olsen, "Fighting Terrorism in Africa by Proxy: The USA and the European Union in Somalia and Mali," European Security, Vol. 23, No. 2 (2014), pp. 290-306; and Alan Taylor, "Operation Barkhane: France's Counterterrorism Forces in Africa," The Atlantic, (October 24, 2017), retrieved from https://www.theatlantic.com/photo/2017/10/operation-barkhane-frances-counter-terrorism-forces-in-africa/543834/.

10. Mohamed O. Hassan, “Turkey Opens Largest Military Base," Voice of America, (September 30, 2017), retrieved from https://www.voanews.com/a/turkey-opens-largest-foreign-military-base-in-mogadishu/4051001.html; Abdirahman Hussein and Orhan Coşkun, "Turkey Opens Military Base in Mogadishu to Train Somali Soldiers," Reuters, (September 30, 2017), retrieved from https://www.reuters.com/ article/us-somalia-turkey-military/turkey-opens-military-base-in-mogadishu-to-train-somali-soldiers-idUSKCN1C50JH; Kaya and Yeşilduman, "Türkiye Osmanlı Topraklarına Geri Dönüyor [Turkey Returns to Ottoman Lands]"; Tom O'Connor, "Turkey's Military to Move into Somalia after Backing Qatar in Gulf Crisis," Newsweek, (August 7, 2017), retrieved from http://www.newsweek.com/turkey-military-move-somalia-backing-qatar-gulf-crisis-646836; and "Turkey to Open It's [sic] Largest Military Base in Somalia," TRT World, (September 30, 2017), retrieved from https://www.trtworld.com/turkey/ turkey-to-open-it-s-largest-military-base-in-somalia-10967.

11. "Why Is Turkey Launching a New Military Training Camp in Somalia?" TRT World, (March 29, 2017), retrieved from https://www.trtworld.com/mea/why-is-turkey-launching-a-new-military-training-camp-in-somalia-326407.

12. Selcan Hacaoğlu, Dana Khraiche, and Glen Carey, "Turkey Adds Troops in Qatar in Defiance of Saudi-led Isolation," Bloomberg, (July 17, 2017), retrieved from https://www.bloomberg.com/news/ articles/2017-07-17/turkey-building-up-army-base-in-qatar-erdogan-adviser-says.

13. Alp Özden, "Turkish Parliament Ratifies Qatar Military Deals," Anadolu Agency, (June 7, 2017), retrieved from http://aa.com.tr/en/middle-east/turkish-parliament-ratifies-qatar-military-deals/836771.

14. Ergan, "Somali'ye Türk Askeri Eğitim Üssü [Turkish Military Training Base in Somalia]."

15. On the military rationale behind basing forces overseas, refer to Michael Lostumbo et al., Overseas Basing of US Military Forces: An Assessment of Relative Costs and Strategic Benefits, (Santa Barbara: Rand Corporation, 2013).

16. This number is expected to rise, but not to exceed 200 military personnel and/or instructors. On the number issue see Ergan, "Somali'ye Türk Askeri Eğitim Üssü [Turkish Military Training Base in Somalia]."

17. For a definition that uses a sender's use rights over a host's territory to demarcate what is and what is not a base, refer to Sebastian Schmidt, "Foreign Military Presence and the Changing Practice of Sovereignty: A Pragmatist Explanation of Norm Change," American Political Science Review, Vol. 108, No. 4 (2014), p. 818; and Robert E. Harkavy, "Thinking about Basing," Naval War College Review, Vol. 58, No. 3 (2005), pp. 12-42. 
18. Turkey reportedly has a 50-year lease or concession for the Mogadishu Airport and a 20-year lease for the Port of Mogadishu, refer to Abdi S. Omar and Mohamed A. Ahmed, "Turkish Aid - Short Gains and Long-term Dependence," ASAS Foundation - Institute for Governance Solutions, (February 2018). The plausible claim on Turkey's territory came via personal correspondence with a Mogadishu-based confidential source (March 8, 2018).

19. For a more general discussion on use rights and degree of control in basing agreements, refer to Alexander Cooley and Hendrik Spruyt, Contracting States: Sovereign Transfers in International Relations, (Princeton: Princeton University Press, 2009).

20. Harun Maruf, "Intel Official Says Turkish Military Base Was 'Target' of Somalia Truck Bomb," Voice of America, (October 17, 2017), retrieved from https://www.voanews.com/a/intel-officials-says-turkeybase-was-bomb-target/4075407.html.

21. During the Cold War, the NATO mission for Turkish forces was to deny the Turkish Straits to the Soviets while taking the major blows from potentially dozens of Soviet and Warsaw Pact divisions. Because NATO viewed the central front in Germany as the decisive theatre in the event of any war, Turkey was given a lower priority in terms of funding and military equipment. Turkish military capabilities were also dealt a blow following U.S. sanctions that were imposed after Turkey invaded northern Cyprus in 1974. On the state of the TAF at the end of the Cold War and its efforts to modernize thereafter, refer to Michael R. Hickok, "Hegemon Rising: The Gap between Turkish Strategy and Military Modernization," Parameters, Vol. 30, No. 2 (2000), p. 109. See also Sonmez Atesoglu, "Turkish National Security Strategy and Military Modernization," Strategic Review, Vol. 29, No. 2 (2001), pp. 26-32.

22. The most prominent of which include Somalia, Bosnia (Turkey sent an army brigade and participated the naval arms embargo against Yugoslavia in the Adriatic), Kosovo (which included a small humanitarian mission to Albania), and Afghanistan.

23. Ali L. Karaosmanoğlu, "The Evolution of National Security Culture and the Military in Turkey," Journal of International Affairs, Vol. 54, No. 1 (2000), p. 212. See also, Edward J. Erickson, "Turkey as Regional Hegemon 2014: Strategic Implications for the United States," Turkish Studies, Vol. 5, No. 3 (2004), pp. 25-45.

24. Turkey's 2000 defense white paper, for example, stated that in addition to classical warfare, the TAF must be prepared to perform activities such as supporting peace, supporting crisis management, providing humanitarian aid and aid in natural disasters, use of limited force, and counter-terrorism. An English language version of the white paper can be retrieved from http://www.css.ethz.ch/en/services/ digital-library/publications/publication.html/154907.

25. Onur Sazak and Auveen E. Woods, "Thinking Outside the Compound: Turkey's Approach to Peacebuilding in Somalia," in Charles T. Call and Cedric de Coning (eds.), Rising Powers and Peacebuilding, (Basingstoke: Palgrave Macmillan, 2017), pp. 167-189; Reşat Bayer and Emin Fuat Keyman, “Turkey: An Emerging Hub of Globalization and Internationalist Humanitarian Actor," Globalizations, Vol. 9, No. 1 (2012), pp. 73-90; and Tarik Oğuzlu, "Soft Power in Turkish Foreign Policy," Australian Journal of International Affairs, Vol. 61, No.1 (2007), pp. 81-97.

26. "Türkiye-Gambiya İlişkileri, [Turkey-Gambia Relations]," Republic of Turkey Ministry of Foreign Affairs, retrieved from http://www.mfa.gov.tr/turkiye-gambiya-siyasi-iliskileri.tr.mfa.

27. Mehmet Özkan and Serhat Orakci, "Turkey as a "Political" Actor in Africa: An Assessment of Turkish Involvement in Somalia," Journal of Eastern African Studies, Vol. 9, No. 2 (2015), pp. 343-352.

28. Turkey reportedly made around $\$ 71$ million in exports to Somalia in 2015 , according to official figures. That number has likely increased but figures are unavailable. As of early 2018, Turkey had invested over $\$ 100$ million in Somalia, according to Turkish Deputy Prime Minister Recep Akdağ who predicted that the bilateral trade volume would rise to $\$ 200$ million from about $\$ 120$ million in 2016 and only \$2 million in 2003. Ty Joplin, "Turkey's Big Play in Africa Starts with Somalia," Albawaba News, (December 4, 2017), retrieved from https://www.albawaba.com/news/original-turkey\%27s-big-playin-africa-starts-with-somalia--1056610; "Türkiye ile Somali Arasında Ekonomik İş Birliği [Economic Cooperation between Turkey and Somalia]," Habertürk, (January 12, 2018), retrieved from http://www. haberturk.com/yerel-haberler/14278773-turkiye-ile-somali-arasinda-ekonomik-is-birligi.

29. Turkey built and opened, in 2013 , one of the largest hospitals in eastern Africa. See, Sinan Uslu, "Türk Hastanesi Somali'de Şifa Dağıtıyor [Turkish Hospital in Somalia Provides Healthcare]," Anadolu Agency, 
(January 20, 2018), retrieved from https://aa.com.tr/tr/dunya/turk-hastanesi-somalide-sifa-dagitiyor/1036321.

30. Cannon, "Turkey in Africa: Lessons in Political Economy," pp. 98-100.

31. Federico Donelli and Ariel G. Levaggi, "Becoming Global Actor: The Turkish Agenda for the Global South," Rising Powers Quarterly, Vol. 1, No. 2 (2016), p. 106.

32. Alice Hills, "Security Sector or Security Arena? The Evidence from Somalia," International Peacekeeping, Vol. 21, No. 2 (2014), p. 171. Hills goes on to point out the problems of overlapping and non-congruent goals in security sector reform of the Somali police: "Although most if not all internationals operate on the assumption that a security sector is desirable and achievable, there are tensions amongst and between actors on how this might be accomplished."

33. Mahad Wasuge, Turkey's Assistance Model in Somalia: Achieving Much with Little, (Mogadishu:The Heritage Institute for Policy Studies, 2016), retrieved from http://www.heritageinstitute.org/wpcontent/uploads/2016/02/Turkeys-Assistance-Model-in-Somalia-Achieving-Much-With-Little1-1.pdf, p. 16. A 2016 report indicates that the airport and harbor fees provided to the SFG are likely many times that officially reported. Abdirazak Fartaag, Breaking Point in Somalia: How State Failure was Financed and by Whom, (Nairobi: Fartaag Consulting, 2016), retrieved from http://fartaagconsulting.com/publications.html. For an analysis of Turkey's path to economic and political influence in Somalia, see, Brendon J. Cannon, “Deconstructing Turkey's Efforts in Somalia," Bildhaan, Vol. 16, No. 14 (2016), pp. 110-116.

34. Wasuge, Turkey's Assistance Model, p. 7.

35. Pınar Akpınar, "Turkey's Peacebuilding in Somalia: The Limits of Humanitarian Diplomacy," Turkish Studies, Vol. 14, No. 4 (2013), p. 740. According to John Aglionby, Mehul Srivastava, and Maggie Fick, in the five years spanning 2011-2016, Turkey committed a total of \$400 million in aid to Somalia: "The Reasons behind Turkey Leader Recep Erdogan's Africa Tour," Financial Times, (June 2, 2016), retrieved from https://www.ft.com/content/aaf3981a-27e5-11e6-8ba3-cdd781d02d89.

36. See, for example, Kantack, "The Gulf Contest."

37. Akpınar, "Turkey's Peacebuilding in Somalia," pp. 735-757; and Cannon, "Deconstructing Turkey's Efforts," pp. 98-123.

38. See in particular, Recep T. Erdoğan, "The Tears of Somalia," Foreign Policy, (October 10, 2011), retrieved from http://foreignpolicy.com/2011/10/10/the-tears-of-somalia/. According to Emel P. Dal and Gonca O. Gök, the Ankara criteria give precedence to a uniquely Turkish vision of international relations seeking to reform the international system, which Turkey sees as unjust, unequal, undemocratic and excessively militarized. Thus, the Ankara criteria are highly normative and moral. Emel P. Dal and Gonca O. Gök,'Locating Turkey as a 'Rising Power' in the Changing International Order: An Introduction," Perceptions, Vol. 19, No. 4 (2014), pp. 5-6.

39. Paul Kubicek, Emel P. Dal, and H. Tarık Oğuzlu, Turkey's Rise as an Emerging Power, (London: Routledge, 2016); and Halil Karaveli, “Erdogan's Journey: Conservatism and Authoritarianism in Turkey," Foreign Affairs, Vol. 95, No. 6 (2016), pp. 121-130.

40. Stuart Williams, "Pantomime Warriors No Joke for Turkey's Erdogan," AFP, (January 22, 2015), retrieved from https://www.yahoo.com/news/pantomime-warriors-no-joke-turkeys-erdogan-040846498.html.

41. Mathew T. Gullo, Turkey's Somalia Adventure: The Quest for Soft Power and Regional Recognition, (London: Research Turkey, 2012), p. 5. See also Cannon, “Deconstructing Turkey's Efforts," pp. 107-108.

42. "Türk Silahlı Kuvvetleri'nin Barışı Destekleme Harekâtlarına Katkıları, [List of Peace Support Missions of the Turkish Armed Forces]," Türk Silahlı Kuvvetleri, retrieved from http://www.tsk.tr/Sayfalar?viewName= BarisiDestekleme.

43. Carol Atkinson, Military Soft Power: Public Diplomacy through Military Educational Exchanges, (Lanham: Rowman \& Littlefield, 2014); and Alexandra Gheciu, "Security Institutions as Agents of Socialization? NATO and the 'New Europe,"' International Organization, Vol. 59, No. 4 (2005), pp. 973-1012.

44. This includes the MPT-76 rifle, over 400 of which were delivered to a company-sized Somali army unit which graduated from the Turkish military training camp in late December 2017. See, Harun Maruf, "Turkey Gives Weapons to Somali Soldiers," Voice of America, (January 5, 2018), retrieved from https:// www.voanews.com/a/turkey-gives-weapons-to-somali-soldiers-/4193724.html; Harun Maruf, "Türkiye 
Somali Ordusunu Silahlandırıyor, [Turkey Is Arming Somalia's Army]," Artı Gerçek, (January 5, 2018), retrieved from https://www.artigercek.com/turkiye-somali-odusunu-silahlandiriyor; and Göksel Yıldırım, "Milli Tüfek Sınırları Aştı [Turkish-made Rifle to Be Delivered Abroad]," Anadolu Agency, (October 31, 2017), retrieved from http://aa.com.tr/tr/ekonomi/milli-tufek-sinirlari-asti/952261?amp=1.

45. Hills, "Security Sector or Security Arena," p. 170.

46. "Turkey Opens Largest Overseas Army Base in Somalia," Al Jazeera, retrieved October 1, 2017, from https://www.youtube.com/watch?v=FdFiDUEGZ6U.

47. On the hierarchy in relations between states, see, David A. Lake, Hierarchy in International Relations, (Ithaca: Cornell University Press, 2004).

48. Jeffrey Herbst, States and Power in Africa: Comparative Lessons in Authority and Control, (Princeton: Princeton University Press, 2014), pp. 3, 5-11.

49. On this pressing issue, refer to Brendon Cannon and Ash Rossiter, "Ethiopia, Berbera Port and the Shifting Balance of Power in the Horn of Africa," Rising Powers Quarterly, Vol. 2, No. 4 (2017), pp. 7-29.

50. Mikolaj Radlicki, "Who Really Rules Somalia? - The Tale of Three Big Clans and Three Countries," Mail \& Guardian Africa, (May 19, 2015), retrieved from http://mgafrica.com/article/2015-05-18-whoreally-rules-somalia-the-tale-of-three-clans; Travis A. Ridout, "Somalia Is Not a State," Huffington Post, (July 13, 2011), retrieved from https://www.huffingtonpost.com/timothy-a-ridout/somalia-is-not-astate_b_894734.html; Hibaaq Osman, "Who Is Really in Control in Mogadishu?" Huffington Post, (June 9, 2017), retrieved from https://www.huffingtonpost.com/entry/who-is-really-in-control-in-mogadishu_us_59affb2ce4b0c50640cd6372.

51. Sahal80, "3000 Galmudug Forces to Be Sent to the Turkish Base in Mogadishu," Somali Net Forums, (April 4, 2017), retrieved from https://www.somalinet.com/forums/viewtopic.php?f=250\&t= 384151\&sid=1f6e71f19a9d37b6da8da29255d7e21a.

52. Harun Maruf, "AMISOM Says 1,000 Troops to Leave Somalia," Voice of America, (November 7, 2017), retrieved from https://www.voanews.com/a/african-union-force-begins-withdrawal-from-somalia/4104674.html. As of 2017, Uganda, Burundi, Kenya, Ethiopia and Djibouti supplied the force of 22,000 AMISOM troops.

53. Harun Maruf, "Turkish Base Key to Building Strong Somali Army," Voice of America, (October 3, 2017), retrieved from https://www.voanews.com/a/turkey-base-somalia-army/4054625.html.

54. Maruf, "Turkish Base Key to Building Strong Somali Army." While the deadline for AMISOM's withdrawal has been formalized, the African Union (AU) has also noted its concerns about the deadline, adding that the mission's mandate may be extended given that the training and equipping of an effective SNA may take longer than expected.

55. Department for International Development, Foreign and Commonwealth Office, and Ministry of Defence, London Somalia Conference 2017: Security Pact, (London: UK Government, 2017), retrieved from https://www.gov.uk/government/publications/london-somalia-conference-2017-security-pact.

56. Dawit Yohannes Wondemagegnehu and Daniel G. Kebede, "AMISOM: Charting a New Course for African Union Peace Missions," African Security Review, Vol. 26, No. 2 (2017), pp. 199-219.

57. Hills, "Security Sector or Security Arena," p. 166.

58. Uzi Rabi, The Emergence of States in a Tribal Society: Oman under Sa'id bin Taymur, 1932-1970, (Brighton: Sussex Academic Press, 2006), p. 3.

59. Paul D. Williams and Abdirashid Hashi, Exit Strategy Challenges for the AU Mission in Somalia, (Mogadishu: Heritage Institute for Policy Studies, 2016).

60. "Kenya Denies Training 2,500 Somali troops," Daily Nation, (February 7, 2010), retrieved from https:// www.nation.co.ke/News/-/1056/857354/-/vq14aq/-/index.html; "Kenya Reportedly Rejects Somali Request to Deploy Troops," Voice of America, (March 31, 2010), retrieved from https://www.voasomali. com/a/kenya-reportedly-rejects-somali-request-to-deploy-troops-89653467/1252396.html.

61. Anne Backhaus and Johannes Korge, "An Army for Somalia: Success Uncertain for European Training Effort," Der Spiegel, (October 22, 2012), retrieved from http://www.spiegel.de/international/world/german-soldiers-help-train-somali-soldiers-at-camp-in-uganda-a-861885.html. 
62. This is not a new development by any means. Former SFG president Hassan Sheikh Mohamud reportedly packed key ministries such as justice, interior and the minister of state for the presidency with his cronies who then were able to settle personal scores. See, Matt Bryden, Somalia Redux?: Assessing the New Somali Federal Government (Lanham: Rowman \& Littlefield, 2013), p. 8.

63. Abdi Sheikh and Feisal Omar, "Raid on Senator's Home Reveals Divisions in Somali Security Forces," Reuters, (December 30, 2017), retrieved from https://www.reuters.com/article/us-somalia-security/ raid-on-senators-home-reveals-divisions-in-somali-security-forces-idUSKBN1EO0G5.

64. Ioan M. Lewis, Understanding Somalia and Somaliland: Culture, History and Society, (London: Hurst and Company, 2008), Chapter 3.

65. See the comments of Turkish General Hulusi Akar in "Somali'de Türk Askeri Üssü, [Turkish Military Base in Somalia]" Sözcü, (September 30, 2016), retrieved from http://www.sozcu.com.tr/2016/gundem/ somalide-turk-askeri-ussu-1420157/.

66. Hussein and Coşkun, "Turkey Opens Military Base."

67. Sinem Cengiz, "What Is at Stake for Turkey in Somalia," Arab News, (October 21, 2017), retrieved from http://www.arabnews.com/node/1180881/columns; Einat Elazari, "Turkey's Southern Ambitions," Global Risk Insights, (February 18, 2018), retrieved from https://globalriskinsights.com/2018/02/turkeys-africa-influence/.

68. Kaya and Yeşilduman, "Türkiye Osmanlı Topraklarına Geri Dönüyor [Turkey Returns to Ottoman Lands]."

69. Hans-Georg Ehrhart and Kerstin Petretto, "Stabilizing Somalia: Can the EU's Comprehensive Approach Work?" European Security, Vol. 23, No. 2 (2014), pp. 179-194.

70. Jack Moore, "Trump Doubles U.S. Forces in Somalia to Fight ISIS and AI-Shabab, Most since Black Hawk Down," Newsweek, (November 20, 2017), retrieved from http://www.newsweek.com/trump-doubles-us-forces-somalia-fight-isis-and-al-shabab-most-black-hawk-down-716923.

71. Lyrics to "A Puzzlement" from the Rodgers and Hammerstein musical The King and I (first performed in 1951). According to Tarak Barkawi, armed forces dominated by outside powers often only exist "behind a veil of sovereign independence." Quoted from "'Defence Diplomacy' in North-South Relations," International Journal, Vol. 66, No. 3 (2011), pp. 597-612.

72. "Why Is Turkey Launching a New Military Training Camp in Somalia?"

73. Andrew M. Scott, The Revolution in Statecraft, (Durham: Duke University Press, 1982), p. 11. A similar argument has been made about France and Britain's military links with defense establishments in their former colonies in Africa and the Middle East that were used to generate various forms of influence. See, for instance, Guy Martin, "Continuity and Change in Franco-African Relations," Journal of Modern African Studies, Vol. 33, No. 1 (1995), pp. 1-20.

74. For a discussion on the ways in which bases or overseas military presences can be a method of political and economic patronage, see, Andy Hultquist and Tricia L. Petras, "An Examination of the Local Economic Impacts of Military Base Closures," Economic Development Quarterly, Vol. 26, No. 2 (2012), pp. 151-161.

75. Christopher P. Carney, "International Patron-client Relationships: A Conceptual Framework," Studies in Comparative International Development, Vol. 24, No. 2 (1989), pp. 42-55; Eric Rittinger, "Arming the Other: American Small Wars, Local Proxies, and the Social Construction of the Principal-agent Problem," International Studies Quarterly, Vol. 61, No. 2 (2017), pp. 396-409.

76. "Assessing Turkey's Role in Somalia," International Crisis Group, (October 8, 2012), retrieved from https://www.crisisgroup.org/africa/horn-africa/somalia/assessing-turkey-s-role-somalia.

77. Popular allegations that Turkey only supports one clan and focuses exclusively on developing Mogadishu proliferate in social media. See for example, Calaf Doon, "Re: Comments regarding Turkey in Somalia [Comment on online chat forum]," (September 18, 2016), retrieved from https://www.somalispot. com/threads/the-turkish-military-base.13967/\#post-303673.

78. Hills, "Security Sector or Security Arena," pp. 165-180; Ahmed Ibrahim, "Out of Control Villa Somalia Attacks Opposition Political Figures," Wardheer News, (January 2, 2018), retrieved from http://www. wardheernews.com/out-of-control-villa-somalia-attacks-opposition-political-figures/. 
79. Barkawi, "'Defence Diplomacy' in North-South," p. 611.

80. M. A. Egge, "Somaliland: Armed Forces Commemorate 24 ${ }^{\text {th }}$ Anniversary," Horn Diplomat, (February 4, 2018), retrieved from http://www.horndiplomat.com/2018/02/04/somaliland-armed-forces-commemorate-24th-anniversary/.

81. “Dozens Killed after Ceasefire Breach in Somalia's Puntland and Galmudug," DW, (November 6, 2016), retrieved from http://p.dw.com/p/2SF86.

82. At the political and intra-state level, Turkey supports national reconciliation and the preservation of the territorial integrity of the whole of Somalia. See Federico Donelli, "A Hybrid Actor in the Horn of Africa: An Analysis of Turkey's Involvement in Somalia," in Aleski Ylönen and Jan Záhořík (eds.), The Horn of Africa Since the 1960s: Local and International Politics Intertwined, (Abingdon: Routledge, 2017), pp. 158-170.

83. For example, the United States reportedly trained and equipped AMISOM contingents and Somali counterterrorism units. See, Katherine Zimmerman, Jacqulyn M. Kantack, Colin Lahiff, and Jordan Indermuehle, "US Counterterrorism Objectives in Somalia: Is Mission Failure Likely?" Critical Threats, (March 1, 2017), retrieved from https://www.criticalthreats.org/analysis/us-counterterrorism-objectives-in-somalia-is-mission-failure-likely. The European Union Training Mission reportedly provided training and assistance to Somali government forces and security institutions. In an effort to train some of Somalia's counter-terrorism forces, in 2015, the UAE opened a new training center in Mogadishu. The country also reportedly provided armored vehicles to Somali forces and pledged in October 2015 to pay Somalia National Army (SNA) salaries. The UAE reportedly has no official military presence on the base. See, Kantack, "The Gulf Contest." Qatar has also reportedly been recruiting and training mercenary troops from the autonomous region of Puntland for unidentified purposes. See, "Qatar Recruiting Soldiers in Somalia for Combat," Garowe Online, (October 13, 2017), retrieved from https://www.garoweonline.com/en/ news/somalia/somalia-qatar-recruiting-soldiers-in-somalia-for-combat.

84. Zakaria Yusuf and Abdul Khalif, "The Regional Risks to Somalia's Moment of Hope," International Crisis Group, (February 22, 2016), retrieved from https://www.crisisgroup.org/africa/horn-africa/somalia/ regional-risks-somalias-moment-hope; Osman, "Who Is Really in Control in Mogadishu?"

85. Canuck, "Re: Comments about Ethiopia and Kenya."

86. Abdi Dahir, "Scramble for the Seas: The UAE Is Expanding Its Influence in the Horn of Africa by Funding Ports and Military Bases," Quartz, (April 11, 2017), retrieved from https://qz.com/955585/in-somaliaand-eritrea-the-united-arab-emirates-is-expanding-its-influence-by-building-ports-and-funding-military-bases/; Ayman Shabana, "Dimensions of the Turkish Role: Reasons behind Turkey's Military Base in Somalia," Future for Advanced Studies and Research, (April 11, 2017), retrieved from https://futureuae. $\mathrm{com} / \mathrm{m} /$ Mainpage/Item/2686/dimensions-of-the-turkish-role-reasons-behind-turkeys-military-basein-somalia; Ahmed Soliman, "Gulf Crisis Is Leading to Difficult Choices in the Horn of Africa," Chatham House, (June 29, 2017), retrieved from https://www.chathamhouse.org/expert/comment/gulf-crisis-leading-difficult-choices-horn-africa.

87. "Oil and Fire: The Intersection of Influence in Somalia between Turkey and the UAE," Sayruuq, (October 6, 2017), retrieved from http://www.sayruuq.com/oil-and-fire-the-intersection-of-influence-in-somalia-between-turkey-and-the-uae/.

88. "In the Race between the UAE and Turkey, Somalia Wins," Stratfor.

89. Martina Schwikowski, "Qatar-Gulf Crisis Spreads to Africa," DW, (August 29, 2017), retrieved from http://p.dw.com/p/2iz0e.

90. Rashid Abdi, "A Dangerous Gulf in the Horn: How the Inter-Arab Crisis is Fuelling Regional Tensions," International Crisis Group, (August 3, 2017), retrieved from https://www.crisisgroup.org/middle-eastnorth-africa/gulf-and-arabian-peninsula/dangerous-gulf-horn-how-inter-arab-crisis-fuelling-regionaltensions.

91. Manning was referring specifically to police culture in the U.S. and UK but this likely applies to Ankara's vision of what a trained SNA would look like. Peter Manning, "A Dialectic of Organisational and Occupational Culture," in Megan O'Neill, Monique Marks and Anne-Marie Singh (eds.), Police Occupational Culture: New Debates and Directions, (Oxford: Elsevier, 2007), pp. 47-83. 